\title{
New Microscopic Model of the Staebler-Wronski Effect in Hydrogenated Amorphous Silicon
}

\section{H.M. Branz}

National Renewable Energy Laboratory

Presented at the National Center for Photovoltaics Program Review Meeting Denver, Colorado

September 8-11, 1998

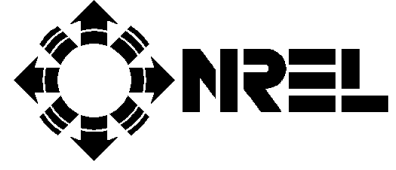

National Renewable Energy Laboratory 1617 Cole Boulevard Golden, Colorado 80401-3393

A national laboratory of the U.S. Department of Energy Managed by Midwest Research Institute for the U.S. Department of Energy under contract No. DE-AC36-83CH10093

Work performed under task number PV904101

October 1998 


\begin{abstract}
NOTICE
This report was prepared as an account of work sponsored by an agency of the United States government. Neither the United States government nor any agency thereof, nor any of their employees, makes any warranty, express or implied, or assumes any legal liability or responsibility for the accuracy, completeness, or usefulness of any information, apparatus, product, or process disclosed, or represents that its use would not infringe privately owned rights. Reference herein to any specific commercial product, process, or service by trade name, trademark, manufacturer, or otherwise does not necessarily constitute or imply its endorsement, recommendation, or favoring by the United States government or any agency thereof. The views and opinions of authors expressed herein do not necessarily state or reflect those of the United States government or any agency thereof.
\end{abstract}

Available to DOE and DOE contractors from:

Office of Scientific and Technical Information (OSTI)

P.O. Box 62

Oak Ridge, TN 37831

Prices available by calling 423-576-8401

Available to the public from:

National Technical Information Service (NTIS)

U.S. Department of Commerce

5285 Port Royal Road

Springfield, VA 22161

$703-605-6000$ or $800-553-6847$

or

DOE Information Bridge

http://www.doe.gov/bridge/home.html 


\title{
New Microscopic Model of the Staebler-Wronski Effect in Hydrogenated Amorphous Silicon
}

\author{
Howard M. Branz \\ National Renewable Energy Laboratory \\ 1617 Cole Blvd., Golden, CO 80401
}

\begin{abstract}
A new microscopic and kinetic model of light-induced metastability in hydrogenated amorphous silicon $(\mathrm{a}-\mathrm{Si}: \mathrm{H})$ was recently proposed. Carrier recombination excites $\mathrm{H}$ from deep $\mathrm{Si}-\mathrm{H}$ bonds into a mobile configuration, leaving a threefold-coordinated $\mathrm{Si}$ dangling bond (DB) defect at the site of excitation - a process long suspected to be an element of metastable DB production. Normally, mobile $\mathrm{H}$ are recaptured at DB defects and neither metastability nor net $\mathrm{DB}$ production results. However, when two mobile $\mathrm{H}$ collide, they form a metastable two-hydrogen complex and leave two spatially-uncorrelated Staebler-Wronski DBs. The model leads to differential equations describing the evolution of the mobile $\mathrm{H}$ and DB densities and a variety of new predictions. New directions for improving the stability of a-Si:H are discussed.
\end{abstract}

\section{INTRODUCTION}

Over 20 years ago, Staebler and Wronski (SW) discovered light-induced metastability in hydrogenated amorphous silicon (a-Si:H) (1). The density of neutral threefold-coordinated dangling bond (DB) defects increases by one to two orders of magnitude as a result of illumination or carrier injection (2). These DBs are metastable; they can be annealed away by about 2 hours heating at $150^{\circ} \mathrm{C}(1)$. Because DBs act as carrier recombination centers and traps in a-Si:H, the metastable DBs cause significant performance degradation of photovoltaic and other devices made from a-Si:H. Numerous microscopic and kinetic models of the SW effect have been proposed and are reviewed elsewhere (3-5). However, all of these models appear to be incompatible with certain experiments (5-7).

I have recently developed a new "H collision" model of the SW effect (5-7). The microscopic model leads to differential equations describing the evolution of the mobile $\mathrm{H}$ and $\mathrm{DB}$ densities and to a variety of new predictions. This microscopic and kinetic model is consistent with the main experimental SW results, predicting 1) isolated SW DB defects uncorrelated with $\mathrm{H}$ or other DBs, 2) an intrinsic creation mechanism, 3) $N_{d b} \sim G^{2 / 3} t^{1 / 3}$ DB creation kinetics at room temperature, 4) light-induced annealing of DBs resulting in saturation at $\left.\mathrm{N}_{\mathrm{sat}} \sim \mathrm{G}^{1 / 3}, 5\right) \mathrm{N}_{\mathrm{db}} \sim \mathrm{t}^{1 / 3} \mathrm{DB}$ creation kinetics at $4.2 \mathrm{~K}$, and 6) $N_{d b} \sim t^{1 / 2}$ laser-pulse $D B$ creation kinetics. In this paper, I present an abbreviated 
description of the microscopic model and outline possible directions for improving the stabilized properties of a-Si:H. Rigorous derivations of the main results and predictions are found elsewhere (5-7).

\section{H COLLISION MODEL}

In the $\mathrm{H}$ collision model (5-7) of the SW effect, DBs are created when light-induced carriers stimulate emission of mobile $\mathrm{H}$ from $\mathrm{Si}-\mathrm{H}$ bonds (normally about 10 at.\%), according to:

$$
\text { Si-H ---> DB + Si-H/DB. }
$$

The mobile $\mathrm{H}$ is labelled here by $\mathrm{Si}-\mathrm{H} / \mathrm{DB}$ because calculations by Biswas et al. (8) show that mobile $\mathrm{H}$ break $\mathrm{Si}-\mathrm{Si}$ bonds and form $\mathrm{Si}-\mathrm{H}$ bonds as they hop between $\mathrm{Si}-\mathrm{Si}$ sites. Each broken $\mathrm{Si}-\mathrm{Si}$ bond reforms as the mobile $\mathrm{H}$ hops away. Mobile $\mathrm{H}$ is weakly bound compared to $\mathrm{H}$ in normal $\mathrm{Si}-\mathrm{H}$ bonds; mobile $\mathrm{H}$ diffuses rapidly through a-Si:H (9).

Mobile $\mathrm{H}$ reverts to immobile $\mathrm{Si}-\mathrm{H}$ through one of two mechanisms. Most often, it retraps to an immobile DB:

$$
\mathrm{Si}-\mathrm{H} / \mathrm{DB}+\mathrm{DB} \quad--->\mathrm{Si}-\mathrm{H},
$$

the inverse process to Eqn. (1). Taken together, Eqns. (1) and (2) neither create nor destroy DBs.

Infrequently, $\mathrm{H}$ retraps by associating with another mobile $\mathrm{H}$ in a metastable complex containing two $\mathrm{Si}-\mathrm{H}$ bonds in close proximity:

$$
\mathrm{Si}-\mathrm{H} / \mathrm{DB}+\mathrm{Si}-\mathrm{H} / \mathrm{DB} \quad--->\mathrm{M}(\mathrm{Si}-\mathrm{H})_{2} \text {. }
$$

Eqn. (3) is the key step of SW defect creation. The reaction annihilates two mobile DBs and forms no DBs, consistent with bond-counting constraints. Combining Eqns. (1) and (3), the net reaction leaves DB defects at.the sites of the original $\mathrm{H}$ excitation according to:

$$
2 \mathrm{Si}-\mathrm{H}--->2 \mathrm{DB}+2 \mathrm{Si}-\mathrm{H} / \mathrm{DB}--->2 \mathrm{DB}+\mathrm{M}(\mathrm{Si}-\mathrm{H})_{2} \text {. }
$$

The created SW DBs appear on the rightmost side of Eqn. (4). The $\mathrm{H}$ atoms are slightly less stable in $\mathrm{M}(\mathrm{Si}-\mathrm{H})_{2}$ than in $\mathrm{Si}-\mathrm{H}$, and the created $\mathrm{DBs}$ are therefore metastable. 


\section{NEW DIRECTIONS FOR BETTER STABILITY}

The $\mathrm{H}$ collision model provides new perspective and therefore suggests new directions that may be taken to improve the stability of a-Si:H materials and devices. Certainly, reduction of $\mathrm{H}$ content could reduce the metastability; perhaps this was already observed in the improved stability of hot-wire a-Si:H containing about 1 at.\% $\mathrm{H}$ (10). However, stabilized defect density increases only as the two-thirds power of $\mathrm{H}$ content (5-7), and some $\mathrm{H}$ is needed to relieve strain, so this tactic may not yield further dramatic improvements.

A more subtle approach would be to increase the diffusion rate of mobile $\mathrm{H}$. This

- may increase the retrapping rate of Eqn. (2) and thereby reduce the mobile H concentration. Improved ordering may be a key to this approach. Finally, it may be helpful to grow a-Si:H with "benign" $\mathrm{H}$ stored in excess $\mathrm{M}(\mathrm{Si}-\mathrm{H})_{2}$, but without an increase of the $\mathrm{DB}$ or isolated $\mathrm{Si}-\mathrm{H}$ densities. This $\mathrm{H}$ would form a reservoir of $\mathrm{H}$ that light could liberate (5-7) by the reverse reaction of Eqn. (3). Light-induced annealing of defects by the reverse of Eqn. (4) should then improve stabilized properties.

\section{ACKNOWLEDGMENTS}

The author gratefully acknowledges many stimulating discussions with P. Tzanetakis and the NREL Amorphous Silicon Team. The research was largely supported by the U.S. DOE under contract DE-AC36-83CH10093. The Fulbright Foundation and the Foundation of Research and Technology Hellas in Greece supplied additional financial support.

\section{REFERENCES}

1. D. L. Staebler and C. R. Wronski, Appl. Phys. Lett. 31, 292 (1977).

2. H. Dersch, J. Stuke, and J. Beichler, Appl. Phys. Lett. 38, 456 (1981).

3. H. Fritzsche, in Amorphous and Microcrystalline Silicon Technology-1997, 467, edited by E. A. Schiff, M. Hack, S. Wagner, R. Schropp, and I. Shimizu (Materials Research Society, Pittsburgh, 1997), p. 19.

4. M. Stutzmann, in Amorphous and Microcrystalline Silicon Technology-1997, 467, edited by E. A. Schiff, M. Hack, S. Wagner, R. Schropp, and I. Shimizu (Materials Research Society, Pittsburgh, 1997), p. 37.

5. H. M. Branz, unpublished.

6. H. M. Branz, Solid State Commun. 105/6, 387 (1998).

7. H. M. Branz, in Amorphous and Microcrystalline Silicon Technology-1998, 507, edited by S. Wagner, M. Hack, H. M. Branz, R. Schropp, and I. Shimizu (Materials Research Society, Pittsburgh, 1998), in press.

8. R. Biswas, Q. Li, B. C. Pan, and Y. Yoon, Phys. Rev. B 57, 2253 (1998).

9. H. M. Branz, S. E. Asher, and B. P. Nelson, Phys. Rev. B 47, 7061 (1993).

10. A. H. Mahan and M. Vanecek, in Amorphous Silicon Materials and Solar Cells, AIP Conf. Proc., 234, edited by B. L. Stafford (AIP, New York, 1991), p. 195. 